\title{
An Example to us all: The Military Approach to the Care of the Injured
}

\author{
- P S London, \\ MBE, C.St.J, MB, BS, FRCS, MFOM, FACEM (Hon) \\ Honorary Consulting Surgeon
}

The Birmingham Accident Hospital

Because this is the eleventh day of the eleventh month I should like this Lecture to be in part a tribute to those that shall not grow old as we that are left grow old. Let us remember them as well as General Mitchiner.

It is a very great privilege to be invited to deliver this Lecture and I am particularly honoured by the fact that the man who issued the invitation, Sir Cameron Moffat, worked with me at the Birmingham Accident Hospital over 20 years ago. Can tolerance, aided perhaps by the blurring of his recollections by the passage of time, be more generously expressed?

The fact that I have known all but one of my predecessors in this honour does something to mitigate the daunting nature of such a distinguished list but it does nothing to diminish my regard for them.

\section{"Mitch"}

Having trained at St Thomas', the name, and some of the reputation, of General Mitchiner were well known to me although I have to admit that when I began my surgical studies in 1941 I was advised to buy Rose and Carless's textbook rather than that by Romanis and Mitchiner. As a medical student one relishes the more ribald and disrespectful anecdotes about one's seniors and Mitchiner provided plenty of material in this respect, but when I came to read the obituary notices in the British Medical Journal and the Lancet - which seemed to go on for longer than for anyone else that I could recall - two anecdotes particularly appealed to me. The first relates to Mitchiner's service in Norway in 1940 as DDMS IV Corps and to some heavy shelling that took place. Mitchiner, who had previously had some pains in his chest, was reported as saying, "My doctors had told me not to hurry, so I acquired a great reputation for bravery"1. The second was recorded by his last House Surgeon, whose "ears still burn at the memory of being told that I looked hungry during a formal dinner at the Royal College of Surgeons and having to accept Mitchiner's own helping passed under the noses of the eminent, and the disapproving frowns of the liveried waiters" $"$.

I met Mitchiner on only two occasions. The first was early in 1944 when I was a Casualty Officer in London. Mitchiner, like any senior officer, was standing with his back to the fire in the Residents' Quarters. He was wearing battledress but with an impressive array of medal ribbons. He and Dr Bamforth, a pathologist, ڤ were engaged in bantering conversation. Dr Bamforth's red face, white hair and rather fierce expression, like. those of Col J C Watts, belied a kindly and humorous nature. On the subject of what they were going to do after the war, Bamforth, pointing at Mitchiner's ribbons, said that he could always get a job as a commissionaire, at which Mitchiner chuckled.

The second time that I met Mitchiner was in 1948, when I was back at Thomas' reading for the Primary FRCS. I had asked him to see my brother, who had injured his fingers playing rugger. When I thanked him for his trouble and apologised for troubling him Mitchiner replied, "Not at all, my boy; glad to see yo back".

These two episodes have much to do with my choice of two more of so many tributes to him. Sir Max Page $\overrightarrow{0}$ wrote of "A certain brusqueness or occasional $\infty$ unorthodoxy of speech seldom hurt the sensitive, if effect being always mitigated by his transparent honest of purpose and by the horse sense which usual characterised his pronouncements". R J V Pulvertaf wrote of others who "were often pulled up short by the simple phrases of a just and serious man whose sense of $\stackrel{\square}{2}$ duty crowned him with a dignity he feigned to despise". $\overrightarrow{0}$ Mitchiner might have acknowledged, even if not $\exists$ outwardly, the truth of such a tribute but he would surely have applauded wholeheartedly what Pulvertaft said on another occasion: "Committees are necessary evils; but they are largely staffed by men too lazy, too old or too inefficient to manage their own affairs, seeking in extenuation to manage those of others".

Sir Heneage Ogilvie ${ }^{4}$ wrote of "the clear cut features and the piercing eyes of a mediaeval Pope" and of his language as "direct, forcible, almost Chaucerian in its imagery". I never met Sir Heneage but I know Sir Ian Fraser well enough to picture the twinkle in his eye when he described Mitchiner's papal appearance and added that his language would not always have been accepted $ᄋ$ in the Vatican ${ }^{5}$. I presume that when he said that, Sir Ian was not referring to any shortcomings in Mitchiner's Latin.

The theme that I have chosen in my attempt to pay due tribute to a great man is one that has featured to some extent in many previous Mitchiner Lectures, and $\omega$ some others ${ }^{6}$. The message that I wish to convey has 
been stated with elegant clarity by Fulton?. "It is not commonly realised that many of the most significant advances in medical science have been made by Medical Officers in the Armed Forces or by civilian physicians working under the stimulus of wartime exigency ... the ultimate compensations of war in the field of medicine have been numerous and many of them highly important". In the same vein, Sir Clifford Allbutt said, "How varied is the experience in the battlefield, and how fertile the blood of warriors in raising good surgeons". This is not to ignore the fact that many of the Army's outstanding performances in the medical field have had a source in civil practice and research, and even administration. Who has had a greater influence on the Army than Florence Nightingale ${ }^{8}$ ? Great as has been the Army's contribution to the care of the injured, it hardly bears comparison in terms of lives saved with the fact that the last 100 years or so have seen an almost incredible change in the ways in which soldiers can be kept fighting fit in the most disease-ridden and climatically unfavourable parts of the world.

\section{Medical Services in Ancient Wars}

Man is a violent animal and throughout his existence he has maimed and killed his kind in pursuit of glory, wealth, land, women and religious beliefs. Early records of human conflicts reveal not only appalling brutality but that some men exulted in what they did to their enemies. Presumably, even in those earliest times some took pity on the wounded, whether by putting them out of their misery or by binding up their wounds. There was certainly medical provision in battles in ancient Egypt ${ }^{9}$. The Iliad and The Odyssey include numerous accounts of wounds and their treatment and the armorial bearings of the Royal College of Surgeons of England remind us of Machaon and Podalirius, sons of Asclepios, who followed in father's footsteps. The Romans allocated a surgeon to every legion of 6,000 men and an assistant surgeon to every cohort of 600 . In Greek and Roman times military surgeons were held in esteem; the Romans looked after the health as well as the wounds of their soldiers and they compensated the disabled.

\section{Early Medical Services in European Armies}

Because physicians were forbidden to shed blood and surgeons ranked as mere handymen, the ordinary fighting soldier often had to put up with the attentions of quacks, charlatans and exponents of the crude operations of fairgrounds and farmyards. The disabled were discharged and left to fend for themselves. The competent surgeons attached to Armies were for the most part the personal attendants of the King and his nobles. As Beck ${ }^{10}$ has put it, "Prudent leaders saw to it that they had men of proven medical ability for themselves and their men". Henry V rated the 20 surgeons that he took with him to France in 1415 highly enough to pay them in advance. With regard to the low standing of most surgeons, Beck ${ }^{10}$ has pointed out that although "they were devoid of learning and lacked access to the standard medical writings, (this) was to prove a great asset because it forced them to rely on practical observation and deal with realities". This is to some extent still true, except that all surgeons can now read, even if, like physicians, some of them do not write very well. Cantlie ${ }^{g}$ has reminded us that the knowledge and experience gained in campaigns have benefitted contemporary medicine and surgery, particularly during what he calls the medical dark age that lasted for 300 years after the Moors left Europe in the 15th century. Some of this darkness evidently existed in the Low Countries in 1572 when it was recorded that surgeons treated the sick "to the great distress of the Army" and, presumably, the sick.

Although there was in Italy in the 9th century provision for the collection of wounded men by equipping their horsed Deputati with a second left stirrup, the first state in Europe to arrange for the care of wounded soldiers was Switzerland in the 14th century $^{7}$. This foreshadowed the efforts of Henri Dunant, a Swiss, after the Battle of Solferino in 1859, that led to the establishment of the International Red Cross.

\section{Medical Services in the Standing Army}

Until 1661, an Army was raised when it was requireo and when peace returned, the survivors were disis charged. By the middle of the 16th century an Army was made up of Companies of 100 men with a Captain and 5 Surgeon, who was expected to purchase medica requirements with the $2 \mathrm{~d}$ a month levied from each the soldiers. When the Standing Army was establisheps the intention to provide a medical service for the Arm政 as a whole was indicated by the fact that the first two names on the list of Medical Officers were those of the Surgeon General, James Fountain, and the Physician General, William Currer ${ }^{11}$, but it was a long time before the Army's medical services were able to contribute much to the welfare of soldiers or to civil medical practice. This was not for lack of material but because of the often poor quality of many of the surgeons, the inadequacy of their assistants and the lack of support, and even sympathy, from the Regimental Officers that commanded them. Even as late as 1886, Lord Wolseley regarded the Sanitary Officer as the most useless in the Army and an encumbrance best left at base ${ }^{12}$. Twelve years later, however, the newly established RAMC earned the commendation of Kitchener and 12 decorations for its work in the Sudan. There was no formal training in military surgery and no opportunity for surgeons to meet and share their experiences until $\frac{7}{0}$ the reforms that followed the Crimean War brought an Army Medical School into existence, about 100 years $N$ after Robert Jackson had proclaimed the need for one.

The Standing Army's medical service was based on the Regiment, each having its own Medical Officer and its own hospital. In war, General Hospitals were set up 
and they were staffed by Medical Officers and Other Ranks transferred from fighting units. It does not require much imagination to understand the quality of the staff so formed.

Behind the brilliant victories of Marlborough and Wellington is a story of incompetence, muddle and neglect in many campaigns. So dreadful was the plight of the sick and wounded in some of them that I shudder to think of the conditions in civil life to which the Army offered something preferable, at least to some. Cantlie's description of the Walcheren Campaign ${ }^{13}$ of 1809 made me wonder how as many as 16,000 of the 39,000 British troops taking part survived the appalling conditions. Only 217 fell in battle. In the better known adversities of the Crimea, over one third of the 28,000 men died of disease and the weather ${ }^{12}$.

The plight of soldiers owed much to the presumption that they were expendable, as was movingly expressed by one after the Battle of Solferino: "Ah, Sir, we fought well but now we are being left to die" 14 . Governments were unwilling to spend money on medical services and Commanders (Marlborough and Wellington excepted) paid little heed to the health and surgical care of their troops, which they saw as being of little importance compared with maintaining the supply of military equipment. Even in his early years in India, Colonel Wellesley (as he then was) wrote a very long letter to the Governor-General expounding the need for the Commanding Officer and his Medical Officer to work as a team in promoting the health and welfare of the soldier. Wellington was then twenty eight ${ }^{15}$.

Medical Officers had little authority and were ranked below the most junior Ensign. The result was that those with an understanding of the importance of food, clothing, ventilation, hygiene and sanitation were unable to persuade their seniors in the campaign, or in the Army Medical Department, of the wisdom, the humanity and the economic advantages of the practices that they recommended, and in some cases had implemented with evident success. Such men were to a large extent handicapped by the lack of reliable figures, which McGrigor was the first to require of his subordinates, although in 1793 Surgeon F T Reide published returns of the rates of sickness and mortality in his Regiment in "A view of the Sickness of the Army in Great Britain, America and the West Indies". Some 30 years later, however, Marshall came to be regarded as the father of medical statistics.

\section{Early Military Surgery}

Until about 100 years ago surgical operations were inevitably crude and even brutal but it is remarkable how some of the victims patiently awaited their turn for amputation and bore it with dignity and without complaint. The Earl of Uxbridge remarked that the surgeon's instrument was rather blunt and his pulse never altered during the amputation of his $\mathrm{leg}^{16}$. Speed was the hallmark of the skilful surgeon but one can only marvel at the skill of Guthrie and the fortitude of the patient upon whom he performed disarticulation at the $z$ hip $^{13}$. Having myself carried out this operation, taking $\underset{\otimes}{\mathbb{Q}}$ well over an hour and shedding a good deal of blood in $\Omega$ the process, I have an almost incredulous admiration for 음 Guthrie. I am sure that many of you are aware that not $\stackrel{\circ}{\text { ? }}$ many yards from here a plate describes George James $\vec{\Rightarrow}$ Guthrie as the English Larrey. This is perhaps not a fair $\stackrel{\text { की }}{\rightarrow}$ comparison; Richardson ${ }^{15}$ criticised Larrey both as a man and for confining his surgical attention to the $\overline{\bar{\sigma}}$ Imperial Guard whereas Guthrie, like Mitchiner, was a $\frac{\bar{\rho}}{\vec{T}}$ soldier's surgeon.

For all the horror of their work, not all surgeons were o indifferent to the sufferings of their patients and the $\vec{\sim}$ introduction of chloroform came as a welcome relief to? soldier and surgeon alike. In spite of the known dangers $\overrightarrow{\vec{\omega}}$ of chloroform, it is astonishing that Hall, the Inspector $\stackrel{\sigma}{D}$ General in the Crimea, should have advised against its use in the following words - "However barbarous it may $\bar{?}$ appear, the smart of the knife is a powerful stimulant, $\frac{1}{\omega}$ and it is much better to hear a man bawl lustily, than to $\vec{\omega}$ see him sink silently into his grave". Not many shared this point of view although some soldiers were frightened of chloroform. Gray went on to quote the case of Patrick Kelly of the 44th, who, at his speciad 음 desire, underwent disarticulation of the right shoulde $\vec{\theta}-$ and amputation through the left thigh in quicas succession $^{17}$.

The fact that wounds could heal by first intention hat $\overrightarrow{0}$ long been known, but the teaching of Theodoric in thy $\infty$ 13 th century was rejected and its author was reviled. \&्f the then accepted necessity for suppuration in the process of healing he said, "No error can be greater th this. Such a practice [of promoting suppuration] is indeed to hinder Nature, to prolong the disease, and to prevent the conglutination and consolidation of the wound" 10 . When Hunter elucidated the theory of recovery of wounds by adhesions, Bell described him as "having done more for surgery than any other observation, not excepting the circulation of the blood"13.

Although wounds of the belly were generally regarded as mortal, Guy de Chauliac (1300-67) had drawn forth any injured organ, cleansed it, if necessary sewn it up and put it back.

In general, it is perhaps fair to say that until the middle of the 19 th century the main advances brought about by wars were in the skill and experience of military surgeons rather than in methods of treatment.

\section{The Flowering of Medical Services in the British Army}

The biggest single change in the Army's medical $\frac{D}{2}$ services was the result of the efforts of three civilians Florence Nightingale ${ }^{8}$, Sidney Herbert, the Secretary at $\widetilde{N}$ War, and W H Russell, War Correspondent of The Times. Cantlie ${ }^{13}$ described Herbert as "the first Minister $\mathcal{O}$ who ever set himself the task of saving the life of the soldier". Although in the Peninsular War Wellington's 
increasing trust of $\mathrm{McGrigor}^{18}$ led to improvement in the medical services as far as local conditions and military priorities allowed, there was no lasting benefit. Even a few years later, at Waterloo, there were few surgeons with experience of battle casualties. What a depressing sequel to McGrigor's tribute to "a body of operators such as never was excelled, if ever before equalled" [as in the Peninsular War]. At this time the medical men in the Army were among the best in the profession ${ }^{15}$.

The 40 years of peace after Waterloo resulted in an Army that was quite unprepared for war in the Crimea or anywhere else. Medical conditions were appalling but this was mainly because the efforts of Hall, the Inspector General, were frustrated both locally by Lord Raglan (who later died of cholera in the Crimea) and in London. When a Commission of Enquiry was sent out, its recommendations were similar to those that Hall had already made; he ruefully noted not only this but the contrast between his influence and that of the Commission. Unlike all previous changes in the Army's medical services, those following the Crimean War brought about benefits that were both great and lasting. Outstanding among these was the establishment of the Army Medical School at Fort Pitt, in Chatham, in 1860. This included Chairs in Military Hygiene, Medicine, Pathology and Surgery, which last superseded the Chairs of Military Surgery in Edinburgh and Dublin. A Statistical Branch was set up and it published annual reports on the Health of the Army. As a result, there were many improvements in, for example, food, clothing and the design of barracks and hospitals, but Smith's efforts as Director General to put Medical Officers in command of military hospitals were not successful. However, Medical Officers' status was brought into line with the ranks of the rest of the Army. The Victoria Cross and membership of the Order of the Bath had been available to the Medical Services since 1854 but Medical Officers now became eligible for other honours and decorations, including the appointment of 6 Honorary Physicians and 6 Honorary Surgeons to the Queen.

\section{The Army Medical School and its Chairs}

The Chair of Military Pathology was occupied by William Aitken for 25 years and he was knighted in 1887. The importance of pathology was clearly understood by Miss Nightingale, who wrote, "the aim of our Army School is the prevention of disease, not the record of the harm disease has done" ${ }^{\text {13 }}$. It deserves to be noted that military post mortem examinations as a customary practice preceded those in civilian life.

Thanks to the efforts of E F Parkes, the Chair of Military Hygiene set standards throughout the world but from the point of view of the care of battle casualties, the outstanding appointment was in Military Surgery.

Thomas Longmore, knighted in 1886, occupied this Chair for 33 years after achieving distinction as Deputy Inspector General of Hospitals in the Crimea. He retired in 1893 with an outstanding international reputation in the wide range of subjects related to the surgical and associated care of wounded men. A century after Longmore's appointment, the establishment of a Joint Chair of Military Surgery by the Royal College of Surgeons of England and the Royal Army Medical College marked another great step forward in the academic standing of Military Surgery ${ }^{19}$. Other Joint Chairs were also set up.

It is tempting to see in the Army's remarkable health and state of supply in the China Wars of $1857-60$ one result of this reforming zeal. Nevertheless, from time to time there were civilian attempts to abolish the Army Medical School, notwithstanding the fact that the School of Engineering cost three times as much. Fortunately, the Government was persuaded that peace was the time to teach Medical Officers and others what they needed to know in War.

\section{Further Advances}

The beneficial effects of Lister's work on antiseptics, which military surgeons were surprisingly slow to adopt, eventually reduced mortality from over $70 \%$ to under $20 \%$. Even more valuable advances were made by Almroth Wright in the prevention of cholera, diphtheria and typhoid and undulant fevers.

There was a growing agreement that the medical an $\$$ associated services of the Army needed to be brough $\mathbb{D}$ together under medical command; this was achieved by the Royal Warrant of 23 June 1898, which brought th Royal Army Medical Corps into existence 8 days later.

\section{The Royal Army Medical Corps}

The performance of the new Corps in the Sudan and South Africa brought numerous honours and decorations to all ranks but its surgical prowess was not fully established until the Kaiser's War. This development owed much to the static nature of most of the fighting, to speedier transport (to which motor ambulance cars added usefully to the well established use of hospital ships and ambulance trains ${ }^{20}$ ), to the development of anaesthesia, and to the introduction of blood transfusion.

\section{4-1918}

The rapid retreats in the early months of the war were the worst possible conditions for young surgeons to learn the craft of war surgery and the lessons of their seniors were derived from the entirely different conditions in South Africa. The main differences were the climate, the size of battles and the fact that, unlike the Boers' rifle and shrapnel bullets, German high explosives implanted heavily manured soil in the tissues they had shattered; primary suture was therefore disastrous.

\section{Wounds}

As the war settled down, surgeons were able to compare notes and the Consulting Surgeons that were 
introduced, many from civilian life, by Sir Alfred Keogh in 1905, helped to disseminate rising standards. It quickly became clear that it was not enough merely to dress wounds before evacuation from the Front. In 1915 a memorandum on injuries in war was drawn up by a committee of Consultants under the DGMS in France ${ }^{21}$. The importance of thorough exploration of wounds and the careful removal of dead and damaged tissue was increasingly recognised, with the result that by 1916 delayed primary suture was recommended ${ }^{21}$. Tetanus became almost completely preventable by these measures, aided by the use of antitetanic serum, and a special team, led by Sir David Bruce, visited every suspected case from September 1916 onwards. The value of anti-gas gangrene serum remained doubtful. The memorandum of 1915 was revised in 1917 and all Medical Officers joining the BEF received a copy. Unfortunately, the skill of the surgeons in France was not always matched by that of the surgeons that looked after the wounded once they were back in England. Attempts to disinfect wounds by chemical means were eventually abandoned as being at least ineffectual and at worst inimical to healing and even to drainage. As experience increased and judgment developed it became recognised that primary suture could be successful, and by 1918 it was again in use in carefully selected cases ${ }^{22}$.

\section{Shock}

The relationship of shock to wounding was universally accepted, as was the protective value of rest, warmth, comfortable support, relief from pain, and something to drink. The fact that bleeding played a part was recognised but sequestration of blood, toxins, fatigue and sepsis were also held to be responsible. The Official History ${ }^{21}$ quotes the "Summary of Shock" by Mansell Moulin in the International Encyclopaedia of Surgery of 1882. "There is evidence to show that in cases of established shock there is a diminution in the volume of blood in circulation" but loss into the splanchnic area was blamed. I was interested to find that Wilson tabulated the different types of shock and their characteristics in 1946 but failed to attach any significance to the fact that the only difference he gave between traumatic and haemorrhagic shock was that in the latter the victim had lost blood. ${ }^{23}$

The systematic study of shock began when the fighting became static. In August 1916 Bayliss reported his findings in the treatment of "low blood pressure conditions". Intravenous saline had been used after the Battle of the Somme, but with disappointing results. In February 1917 the Medical Research Committee $\checkmark$ published its first memorandum and 6 months later a special committee was set up to study the subject in forward areas ${ }^{24}$. By then, intravenous gum saline was in use and direct transfusion of blood had been tried as early as 1916. In 1918, Robertson reported on the use of preserved red cells ${ }^{25}$, and Guiou on the use of blood transfusion in a Field Ambulance ${ }^{26}$. Resuscitation teams trained in transfusion were attached to ambulances in shock centres and Divisional Medical Officers trained in $z$ transfusion were placed in well equipped first aid posts $\mathbb{\varnothing}$ and Advanced Dressing Stations where casualties were expected, such as after a trench raid.

In spite of all this, the Medical Research Committee's report on traumatic toxaemia in 1919 left the subject $\overrightarrow{\vec{F}}$ confused by present standards. Primary shock was $\stackrel{?}{+}$ attributed to potentially fatal injuries; the blood pressure fell rapidly and the familiar clinical picture developed. It was stated that, "In war surgery at any rate $\frac{\mathcal{N}}{\vec{D}}$ it is doubtful if such a state of affairs occurred apart from $\stackrel{\varnothing}{\unrhd}$ haemorrhage" ${ }^{21}$. Secondary shock occurred later and more slowly. It seems to have been confused with $\vec{\circ}$ chilling and with early gas gangrene and to have been attributed to the absorption of toxins.

It is interesting to note the recommendation that, of unless the belly was affected, wounded men required something to drink and that cold water was believed to be as good as a hot drink. The recommendation that hot $\frac{\dot{ }}{\omega}$ water bottles be applied to armpits and to the belly was evidently not seen to be harmful.

In spite of the confusion of ideas about the nature and causes of shock there was much to commend in what was done to treat it and to try to prevent it, not least by the training and careful siting of resuscitation teams.

\section{Reception of the Wounded}

The vast numbers of casualties from major battle $\vec{\theta}$ made it necessary to have well defined arrangements for $\infty$ their reception and categorisation for treatment. This was achieved by what was many years later hailed as the new practice of progressive patient care. In 1916 \# enabled CCSs to deal with 1,000 or more casualties a day. I was surprised to find that mobile $X$-ray equipment $\stackrel{\circ}{\varnothing}$ was available in January 1915 and that within 2 years many CCSs were so equipped. I was even more $\overrightarrow{0}$ surprised later to read that X-ray apparatus in the form of a fluorescent screen was in use by the Army in the Sudan within 2 years of Röntgen's discovery of the rays at the end of 1895 and that it was available on the field of battle in India in $1898^{13}$.

\section{Anaesthesia}

Specialist anaesthetists began to emerge in CCSs in $1916^{17}$ and, by 1918,200 specially trained nurses had been added to the anaesthetic services ${ }^{21}$. Once again, 3 . the needs of war had enabled the RAMC to rise to the occasion and, in so doing, to initiate a speciality of incalculable value.

\section{Wounds of the Chest}

Experience of the relatively tidy wounds in South Africa had suggested that these injuries should be $N$ looked after by physicians. This policy did not last long $N$ in the Kaiser's War. Even when the importance of early $N$ aspiration was recognised in 1915, and subsequently in $\omega_{\sigma}$ 1916 that thorough exploration and toilet prevented 
infection, the physicians still had misgivings about what they regarded as the danger of recurrent bleeding after aspiration of an haemothorax. One unit, $36 \mathrm{CCS}$, had the invaluable and instructive experience of being able to retain its casualties until they were convalescent.

The Official History ${ }^{21}$ includes a fascinating review of the treatment of these injuries. Like so many fields of surgery, this was subject to cycles of fashion but it was the RAMC that settled once and for all the arguments that had continued since Mâitre Henri de Mondeville, a pupil of Theodoric, recommended about 600 years before that wounds of the chest should be closed as soon as possible after removing all foreign bodies. (Guthrie did much the same in the Peninsular War). The Official History notes the beneficial effect of morphine after wounds of the chest but does not mention the physicians' reaction to this use of a drug that was regarded as depressing respiration.

Although the value of decortication was pointed out in a memorandum in 1917 , it seems that the operation was little used - perhaps because early re-expansion of the lung made it unnecessary.

\section{Wounds of the Belly}

Once again, the experience of South Africa and previous campaigns was misleading. Sir William MacCormac, who was the subject of Sir Ian Fraser's Vicary lecture ${ }^{27}$, has been quoted as saying of the Boer War, "A man wounded in the abdomen dies if he is operated on, and remains alive if he is left in peace". One may perhaps wonder how many such men rested permanently in peace. Experience in the Balkan War of 1912-13 caused this opinion to be revised and I have already referred to the successful repair of the gut by Guy de Chauliac - and also by de Mondeville - 600 years ago. Early in the Kaiser's War, Richards ${ }^{28}$ reported successful results of gastric suction and drainage of the belly after repair of the gut. The success of this policy was such that special centres for abdominal wounds were set up by detaching surgeons from CCSs to work in ADSs. Unfortunately, this was liable to make evacuation necessary earlier than was sometimes wise ${ }^{21}$. A generation later, Rob $^{29}$ recognised that not all bellies should be operated on; this was because the long and fruitless operations that could result might cost the lives of others who were kept waiting. It is unlikely that he was the first to recognise this danger, which could come into Jackson Burrows' category (pace Oscar Wilde) of the pursuit of the inoperable by the irrepressible. It is a danger to be borne in mind when technically skilful young surgeons are allowed a free hand in the care of multiple civilian casualties.

\section{Organisation of Surgical Services}

As the war went on the need for adaptability became increasingly clear. Not all the practices developed in the static war in France were practicable in other theatres of war, but the principles learned in France could be applied anywhere.

After 1914 it became clear that some surgical teams should be as far forward as possible in the prevailing conditions. The CCS was the hub of the surgical services, in which most of the definitive operations were carried out, but from which surgeons could, if necessary, be attached to Field Ambulances. The Regimental Medical Officer had always been well forward, either 7 paces behind the Colour with his Assistant or at the foot of a breach in defences in bygone times ${ }^{13}$, but these were no places in which to operate.

The difficulties of transport could be formidable but ingenious solutions were devised. A special development in mobility was the establishment of a Mobile Operating Unit for the Desert Mounted Corps in Palestine. The Unit was based on $5 \mathrm{cwt}$ Fords that could cross any country. These vehicles were designed in 1914 and they could be in action in 10 minutes to provide power and act as sterilising and preparation rooms for operations. They were invaluable. ${ }^{21}$ An attempt was also made to put an operating theatre on wheels ${ }^{30}$, but the idea did not seem to prosper. Gissane's experience with a mobile operating theatre in Birmingham in 194753 was no more encouraging ${ }^{31}$. Operating requires spacw and on a vehicle that space can be put to better use fo $\widehat{Q}$ the carriage of equipment packed as neatly as possible In the Mobile Operating Unit mentioned, no packag weighed more than $1501 \mathrm{l}$.

\section{Fractures and Rehabilitation}

At the beginning of the Kaiser's War, amputation was often carried out for open fractures of the tibia and fibula, but, by the end of it, progress had been such that "many brilliant results" had been achieved by bone grafting of gaps in the radius and ulna ${ }^{21}$. Ununited fractures were being plated (Hey Groves ${ }^{32}$ had even used a medullary nail in the humerus) but the poor quality of the metal caused "irritation".

The greatest benefit for the greatest number came from earlier and better splinting under the influence of Sir Robert Jones. Some of the apparatus that he recommended was similar to that in use long before, but the very early application of Thomas' splint with traction was a great improvement on Liston's splint and it came into its own again in North Africa as the Tobruk splint ${ }^{33}$. Even open fractures, which were irrigated with CarrelDakin's solution, did not necessarily prevent patients from being up and about in splints ${ }^{34}$, with their wounds healed in 5-7 weeks ${ }^{21}$. The irrigation probably contributed less to this quality of result than did good surgical toilet.

The other great advance under Sir Robert Jones as Inspector of Military Orthopaedics was the establishment of 17 Rehabilitation Centres, which were the first comprehensive rehabilitation service anywhere ${ }^{21}$. 


\section{Research}

The role of the Medical Research Committee has already been mentioned but the most valuable and widespread research was that done by the surgeons themselves as they became increasingly aware of the healing power of healthy tissues left by thorough toilet and decompression of wounds, followed by mechanical support in the case of the limbs and uninhibited by powerful chemicals. The strength of British Military Surgery has come from offering general guidance rather than laying down rules that restrain the initiative and ingenuity of well trained surgeons. In these matters, the Consulting Surgeons were of inestimable value ${ }^{35}$.

\section{9-45}

Until the Germans invaded the Low Countries in May 1940 , and advanced rapidly to the Channel, the Army had had to put up with poor local sanitation and inadequate material and human resources to deal with it.

As in 1914, the rapid retreat led to enormous confusion, although this did not prevent individual surgeons and their teams from managing remarkably well, operating continuously for 12 and even 16 hours in some cases.

After the fall of France, the need for yet greater mobility was clearly recognised and planned for, with remarkable success in North Africa and thereafter. Cumbersome CCSs were lightened, surgical teams went forward to Field Ambulances in some cases and, as the war went on, more and more use was made of aircraft for supply and evacuation. Of the Burma campaign it was fairly said that the Army advanced on the wings of the Air Force. On the other hand, the risk of attack from the air made it necessary for medical units to dig in without delay and to be widely dispersed.

\section{Special Medical Units}

Field Transfusion Teams, Mobile Neurosurgical Units, often associated with Maxillofacial and Ophthalmic Units as a surgical Trinity, went well forward and provided early and highly skilled care. Assault from the sea and across rivers used selfcontained units such as "breach bricks" with all the equipment they would need until lines of supply and evacuation could be established. None of these could have achieved the level of efficiency that they did without the units and services that kept the troops healthy with the aid of the almost miraculous substances such as penicillin, DDT, mepacrine and chloramphenicol that became available.

Of the medical challenges of the campaign in Italy, $\mathrm{Crew}^{36}$ wrote that "the development of the Army Medical Services reached its highest point. There were critical periods but no disasters and it is to the credit of all concerned that the Director General of Army Medical Services, Sir Alexander Hood, earned and retained the complete confidence of his military superiors, his colleagues and the profession". He "accomplished the task of creating and directing an $z$ organisation that would ensure that the very best $\stackrel{\mathbb{Q}}{\Omega}$ medical, nursing and dental care would be available to $\bigcirc$ those that needed it" and in Italy in 1944 that included 윽 the civilian population. In North West Europe shortly afterwards, Montgomery paid glowing tribute to the $\overrightarrow{\vec{F}}$ RAMC "with admiration and high regard to a Corps $\stackrel{?}{+}$ whose contribution to victory has been beyond all $\bar{c}$ calculation". He acknowledged the enormous benefits $\frac{\bar{\sigma}}{\bar{n}}$ to physical recovery and to morale resulting from the $\frac{\bar{\sigma}}{\partial}$ ready availability of blood, from having surgical teams $\mathbb{Q}$ and nurses well forward and from evacuation by $ڤ$ air ${ }^{13,37,38}$ : Like Marlborough and Wellington, $\vec{\circ}$ Montgomery cared for his men and they trusted him to lead them to victory. No longer was it true to say that $\vec{\omega}$ "Soldiers' lives in the British Army were sacrificed to political expediency and financial stringency"?

\section{Special Fighting Units}

Hitler's War saw the development of a wide range of special units such as the Special Air and Boat Services, $N$ Popski's Private Army, the Long Range Desert Group, which had the privileges of doing no paper work and of getting everything it asked for, and, perhaps the moș famous of all, Wingate's Chindits. Whether se黑 $\vec{C}$ contained or supplied by air, they were very much op their own, which meant that Medical Officers and Oth

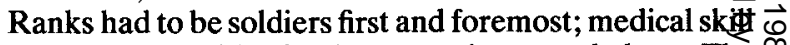
does not provide food, protection or shelter. The $\infty$ Medical Officers were armed for self-protection as we as to protect their patients ${ }^{39}$. A combatant role for Medical Officers goes back to the days when it w⿳⺈ possible to hold a combatant commission as well as being $\vec{\partial}$ a Medical Officer. Even after that was no longer $\stackrel{\circ}{\mathbb{D}}$ possible, Fullerton commanded the defence of Patna in 1760, H T Reide and his sergeant spiked a gun during $\overrightarrow{\vec{O}}$ the Indian Mutiny and, even more remarkable, Guthrie captured a field gun in 1809 . Reynolds won the VC for carrying ammunition under fire at Rorke's Drift and nurses on the North West Frontier learned how to shoot $^{9}$.

\section{Research}

The war stimulated and accelerated the development $\stackrel{0}{\rightleftarrows}$ and use of many drugs and disinfectants as well as means of protection and survival and full use was made of 3 research to establish their value. The Medical Research Council played an invaluable part in this, working closely with the Army Council. Research teams in 0 operational areas wore uniform and the carefully integrated system of military and scientific needs and $\frac{D}{O}$ services worked extremely well ${ }^{40}$. In particular, the subject of shock was brought out of the confusion of $20 \mathrm{~N}$ years before by the work of Grant and Reeve ${ }^{41}$, which $N$ was later extended in civilian casualties by Ruscoe $N$ Clarke at the Birmingham Accident Hospital. His ${ }_{\sigma}^{\omega}$ interests in the subject had been aroused by his 
experience with battle casualties and his work was an outstanding example of the application of knowledge gained in war to the advantage of civil practice.

As before, much valuable information came from the wholehearted efforts of able and devoted men in their everyday work. This was then put to the test of scrutiny by colleagues in discussion and by Consultants on their visits before being published in the Bulletin of War Medicine and official reports and memoranda. As never before, research was everybody's business.

\section{War Surgery Since 1945}

It is a remarkable tribute to the work of the RAMC in France 70 years ago that for all the Corps' later studies of wounding $42,43,44,45,46$, surgical management of injured tissue that was then established has not been improved upon. In both war and peace, wherever resources are scarce, the rule remains - explore and decompress, carry out thorough surgical toilet and close when it is safe to do so $^{47}$. Weston ${ }^{48}$ quoted Eyre-Brook's wise and perceptive comment that poverty in material resources is not matched by poverty of intellect or resourcefulness. It should, however, be added that external skeletal fixation has provided an invaluable technical advance in the treatment of severe open fractures, whether fresh or not, but only as a supplement to sound, basic surgery ${ }^{49,50}$. In contrast, the surgical care of injured men has advanced enormously thanks to the improvements in resuscitation and anaesthesia and the ease, speed and comfort of supply and evacuation by air. Nevertheless, the fighting soldier and his medical brethren-in-arms still have to be prepared to move themselves, their equipment and their wounded entirely by their own efforts until mechanical means of transport can be made available.

Operating in the Falkland Islands required the same ability to make do with meagre resources as did operating in previous campaigns, although having an unexploded bomb in the theatre was perhaps a little unusual $^{51}$.

It is greatly to the credit of all concerned that the Expeditionary Force of 1982 was so well equipped and trained, with all ranks capable as never before of helping their wounded comrades $52,53,54,55$.

\section{Civilian Accident Services}

Although the army has for more than 300 years had arrangements in England for dealing with military casualties from overseas, the first planned accident service in Britain was that set up by Robert Jones when the Manchester Ship Canal was being built from 1888$93^{56}$. The biggest service was that set up (and so thoroughly tested) to deal with air raid casualties of $1939-45^{40}$. The smooth evacuation of half a million school children at the very beginning of the war was a remarkable achievement of masterly planning. As usual, however, once the perceived need passed the service broke up and Britain as a whole has not had an accident service since, despite the many reports and recommendations of the last 30 years ${ }^{57,58,59,60,61,62}$.

In addition to the emergency services in industry and transport, Plewes in Luton, Scott in Oxford and Gissane in Birmingham set up services for the local population. Of the three latter, only Birmingham's, which was so well served by ex-Service medical officers, combined research and teaching with the care of the individual from the time of arrival in hospital, and sometimes even before that, to the stage of final recovery. It also pioneered much research into the causes and prevention of accidents and their effects ${ }^{31}$. In this, it came nearer than any other organization before or since to the spirit and practice of the Royal Army Medical Corps, which in wartime has provided the nation with the finest accident service it has ever had. I cannot help wondering whether anyone has given serious thought to the possibility of turning to the Medical Services of the Armed Forces to provide for one part of the country a first class accident service for the severely injured, similar to that of an American Trauma Centre. The metaphor may not be wholly appropriate but this could kill two birds with one stone by providing a valuable and much-needed service to the public and by training surgeons in the Services.

Technical advances made by the Army's medica services in recent wars have been incorporated intक्षे civilian practice, even, eventually, the compulsore wearing of crash helmets by motor cyclists ${ }^{630}$ Unfortunately, the organisational example has not beerp followed. Apart from Gissane's few years as aर Honorary Professor of Accident Surgery (a personaf Chair), there has been no recognition of the need fot? academic status in civilian accident surgery as well as in military surgery. The Army has to plan for casualties on a large scale and knows how to do it successfully. The challenge of war concentrates the mind wonderfully but in civil life the wide distribution of accidents and the increasing fragmentation of surgery by specialisation has not provided that stimulus. Every young surgeon should be obliged to read The Field Surgery Pocket Book ${ }^{64}$ and Owen-Smith's book ${ }^{65}$ on high velocity missile injuries, and there should be a Mitchiner on every course for the Fellowship and on every Court of Examiners.

Brigadier (later Professor) Stammers wrote in the British Journal of Surgery's War Surgery Supplement ${ }^{33}$, "Throughout the whole war the RAMC was for ever striving for 'something better', and between administrators and working doctors [a nice distinction] there developed a magnificent spirit of co-operation, with the result that during the last year of the war unprecedented standards of results were achieved". And what about this? "We trained hard, but it seemed every time we were beginning to form teams we would be re-organised. I was to learn later in life that we tend to meet every situation by re-organising, and what a wonderful method it can be for creating the illusion of progress while producing confusion, inefficiency and demoralisa- 
tion". Another recent complaint about the Health Service? No, that was written by Gaius Petronius Arbiter in AD 75.

There should be a Mitchiner on every Health Authority.

\section{A Personal Note}

When I was reading the surgical history of the Kaiser's War I did so with great interest and with tremendous admiration for the standards that were achieved. Some of the names I knew, but the main sense of familiarity came from the fact that here was the development of the sort of surgery to which I was introduced at the Birmingham Accident Hospital and which I practised for over 30 years, in far greater comfort and safety than did my unknown exemplars of 1915-18, but to no better effect.

It has been a great honour to be invited to deliver this Lecture. Although my own brief Service was with the Royal Air Force after the War my association with the RAMC goes back nearly 30 years and has been a continuing source of pride and satisfaction. This is not least because of the part that my colleagues at the Accident Hospital and I have been able to play in maintaining some of the standards that were set up by the Royal Army Medical Corps and, as it were, helping to return them to the Army's Medical Officers and Other Ranks, some from fighting units. The distinguished names on this list of those to whom we have been of service (Table 1) will explain my deep sense of privilege.

In the presence of the Surgeon-General I cannot resist the temptation to quote Cantlie's comment about the redoubtable Robert Jackson ${ }^{13}$; "The only man in history to thrash his Surgeon-General in public deserves to be better known". I do not, however, include that performance under the title "An example to us all".

Table 1

\section{RAMC Officers at the \\ Birmingham Accident Hospital 1962-87}

Lieutenant Colonel M A R Eslick Major B T Poole

Major I S Lister

Major R Scott

Major J Iffland

Major W CMoffat

Major D A W Hopkinson

Major I A McCahon

Major I Capperauld

Major D G Stock

Major N A Boyd

Major J T Coull

Major CMacfarlane

Major R P Craig

Major N E Cetti

Major H MWetherill

Major S G Mellor

Lieutenant J B Hull

Lieutenant T Shanks

Lieutenant J Driscoll

\section{REFERENCES}

1. PAGE C M. Obituary notice. Br Med J. 1952; ii: 943.

2. ANON. Obituary notice. Lancet 1952 ; ii: 834 .

3. Pulvertaft R J V. Obituary notice. Lancet 1952; ii: 834

4. OGILVIE W H. Obituary notice. Lancet 1952; ii: 834.

5. FRASER I. The doctor's debt to the soldier. JR Army Med Corps 1972; 118: 60.

6. Drew W R M. Medicine's debt to the Army. J R Army Med Corps 1964; 110: 4.

7. FULTON J F. Medicine, Warfare and History. $J$ Amer Med Ass 1953; 153: 482.

8. Rains A J H. The Nightingale Touch. $J R$ Army Med Corps 1982; 128: 4.

9. Cantlie N. A History of the Army Medical Department. Vol 1. London and Edinburgh. Churchill Livingstone, 1974.

10. BECK R T. The Cutting Edge. London and Bradford. Lund Humphries, 1974.

11. Peterkin A. Commissioned Medical Officers of the Army. Aberdeen University Press, 1925.

12. Lovegrove P. Not least in the Crusade. Aldershot. Gale and Polden, 1951.

13. Cantlie N. A History of the Army Medical Department. Vol 2. London and Edinburgh. Churchill Livingstone, 1974.

14. Mountbatten of Burma. The beginnings of the Red $O$ Cross and some personal reflections. Trans Med Soc Lond 음 1986; 101: 68.

15. RICHARDSON F M. Wellington, Napoleon and the medicale services. J R Army Med Corps 1985; 131: 9 ,

16. ANGLESEY, MARQuess OF. One Leg. London: Jonatha Cape, 1962.

17. Gray T C. Another side of Mars. J R Army Med Corps 1984; 130: 3 .

18. BLANCO R L. Wellington's Surgeon General: Sir James McGrigor. Duke University Press, 1974.

19. BROCK R. Joint Chair of Military Surgery. J R Army Me $\overrightarrow{\vec{A}}$ Corps 1961: 107: 69.

20. Plumridge $\mathbf{J}$ H. Hospital ships and ambulance trains. London. Seeley, Service and Co, 1975.

21. MacPherson W G, et al. Official History of the War. Medical Services, Surgery of War, I, II. London. HMSO, 1922.

22. Bowlby A. Primary suture of wounds at the Front in France. Br Med J 1918; i: 333.

23. WILSON J V. The pathology of traumatic injury. London and Edinburgh. E and S Livingstone, 1946.

24. Medical Research Committee. Special Report Series 25. London HMSO, 1919.

25. RoBERTSON O H. Transfusion with preserved red blood cells. $B r$ Med J 1918; i: 691.

26. Guiou N M. Blood transfusion in a Field Ambulance. $B r$ Med J 1918; i: 695.

27. FRASER I. Sir William MacCormac and his times. Ann $R$ Coll Surg Eng 1983; 65: 339.

28. RichARDS O. Pathology and treatment of gunshot wounds of the small intestine. Br Med J 1915; ii: 213.

29. Rов C G. Military Surgery, our debt to our patients and predecessors. J R Army Med Corps 1986; 132: 11.

30. NoTE. A motor field operating theatre. Br Med J 1916; ii: 今o 271.

31. LoNDON P S. Man and Memorial. Injury 1982; 14:211.

32. Hey Groves $\mathbf{E} \mathbf{W}$. On modern methods of treating fractures. Bristol. Wright, 1916. 
33. Stammers F A R. Wounds of the Extremities. Br J Surg War Surg Suppl 1947; 2: 274.

34. Jones R. Mechanical treatment of compound and suppurating fractures occurring at the seat of war. $\mathrm{Br} \mathrm{Med}$ $J$ 1915; i: 101.

35. EISEMAN B. Preparing the civilian surgeon for combat casualty management. J Trauma $1985 ; 25$ : 151 .

36. CREw F A E. History of the Second World War. The Army Medical Services-Campaigns III. London HMSO, 1959.

37. Silverston P P. Development of an emergency services system - the Israeli example. Injury 1979; 11: 99.

38. Ross J A. Men in Battle. J R Army Med Corps 1980; 126: 4.

39. Talbot N. Guerrilla Surgeon. J R Army Med Corps 1975; 121: 112.

40. MacNalty A S and Mellor W. F. The History of the Second World War. Medical Services at War. London. HMSO, 1968.

41. GRANT R T and ReEve E B. Observations on the general effects of injury in man. Medical Research Council. Special Report Series 277. London HMSO, 1951.

42. Hopkinson D A W and WatTs J C. Studies in experimental missile injuries of skeletal muscle. Proc $R$ Soc Med 1963; 56: 461.

43. Hopkinson D A W. The use of Giemsa stain to demonstrate histologically the extent of altered striated muscle around bullet wounds. J Path Bact 1964; 87: 63 .

44. Thoresby F $\mathbf{P}$ and Darlow $\mathbf{H}$ M. The mechanism of primary infection of bullet wounds. Br J Surg 1967; 54:357.

45. ThOREsBY F P and WatTS J C. Gas gangrene of the high velocity wound. Br J Surg 1967; 54: 25.

46. ScotT R. Pathology of injuries caused by high velocity missiles. Clin Lab Med 1983; 3: 273.

47. DE WIND C M. War injuries treated under primitive circumstances: experiences in a Ugandan mission hospital. Ann R. Coll Surg Eng 1987; 69: 193.

48. WESTON P M. Care of the injured in the Third World-what can we learn? Injury 1987; 18: 297.
49. Ronen G M, Michaelson M and Waisbrod H, 1974; External fixation in war injuries. Injury 1974; 6: 94.

50. Rautio J and PaAvolainen P. Delayed treatment of complicated fractures in war wounded. Injury 1987; 18 238.

51. Jolly R. The Red and Green Life Machine. London. Century Publishing, 1983.

52. MARsh A R. A short but distant war - the Falklands Campaign. $J R$ Soc Med 1983; 76: 972.

53. JACKSON D S, et al. The Falklands War: Army Field Surgical Experience. Ann R Coll Surg Eng 1983; 65: 281.

54 JowitT M D. Anaesthesia ashore in the Falklands. Ann $R$ Coll Surg Eng 1984; 66: 197.

55. Ryan J M. The Falklands War-Triage. Ann $R$ Coll Surg Eng 1984; 66: 195.

56. SEDDON H J. The Manchester Ship Canal and the colonial frontier. J Bone Joint Surg 1961; 43B: 425.

57. Nuffield Provincial Hospitals' Trust. Casualty services and their setting. Oxford University Press, 1960.

58. ACCident SERvices' ReVIEW CommitTeE of Great BRITAIN and IRELAND, 1961; Interim Report. 1971; Report on progress. London. British Medical Association.

59. SubCOMMITTEE ON ACCIDENT SERVICES. London. HMSO 1962.

60. BRUCE J. Report of a Joint Working Party. London. Joint Consultants' Committee, 1971.

61. British ORTHOPAEDIC Association. Casual to Departments. The Accident Commitment. Londord British Orthopaedic Association, 1973.

62. LEWIN W. Medical staffing of accident and emergenco services. London. Joint Consultants' Committee, 1978.

63. Cairns $\mathrm{H}$ and Holbourn A H S. Head injuries in motos cyclists with special reference to crash helmets. $\mathrm{Br}$ Med 1943 ; i: 591

64. FIEld Surgery POCKET BOOK. London HMSO, 1981.

65. OWEN-SMITH M S. High velocity missile wounds. London Edward Arnold, 1981. 